\title{
Familiar Adjustment of the Minors Who Are Victims of Gender-Based Violence and Minors Immersed in a Divorce Process: an Exploratory Study *
}

\section{Conflictividad familiar en menores víctimas de violencia de género y menores inmersos en un proceso de divorcio: un estudio exploratorio}

\author{
Francisco José Trillo-PAdilla ${ }^{a}$ \\ Universidad de Almería, España \\ ORCID: http://orcid.org/0000-0002-2998-3253 \\ Flor Zaldívar-Basurto \\ Universidad de Almería, España \\ ORCID: http://orcid.org/0000-0003-3003-0609 \\ JUAN GARCÍA-GARcía \\ Universidad de Almería, España \\ ORCID: http://orcid.org/0000-0003-2803-4176
}

a Correspondence author. Email: chescotrillo@gmail.com

How to cite: Trillo-Padilla, F. J., Zaldívar-Basurto, F., \& García-García, J. (2019). Familiar adjustment of the minors who are victims of gender-based violence and minors immersed in a divorce process: an exploratory study. Universitas Psychologica, 18(2), 1-10. https:// doi.org/10.11144/Javeriana.upsy18-2.famw

\begin{abstract}
The differences in the psychosocial and family adaptation of a group of minors derived to the Family Meeting Point of Almeria are analyzed, also the caretaking capacity of their parents, depending on whether they come from the Gender Violence Court (GVC) or Family Court (FC) and the level of family conflict reported by the minor and parents. We studied 15 families in two groups in the divorce process, one consisting of 8 children of families from GVC and another of 7 children of the FC. When analyzing the reported family conflict, most of the children have witnessed episodes of violence at home, $75 \%$ of the GVC. $42 \%$ of children under FC would change their visitation regime. We observed statistically significant differences in terms of this conflict in family and school maladjustment. It is discussed to assess the needs of the minor considering their preferences regarding the visitation regime to decide juridically and psychologically.

Keywords

Gender-based violence; minors; victims; family meeting points; familiar dispute.
\end{abstract}

\section{RESUMEN}

Se analizan las diferencias en la adaptación psicosociofamiliar de un grupo de menores derivados al Punto de Encuentro Familiar de Almería, así como la capacidad cuidadora de sus progenitores, en función de si provienen del Juzgado violencia género (JVG) o del Juzgado Familia (JF) y del nivel de conflictividad familiar informado por el menor y progenitores. Estudiadas 15 familias en dos grupos en proceso de divorcio, uno formado por 8 menores de familias del JVG y otro de 7 menores del JF. Al analizar la conflictividad familiar informada, la mayoría de los menores han presenciado episodios de violencia en casa, el 75\% del JVG. El 42\% de menores del JF cambiaría su régimen de visitas. Observadas diferencias estadísticamente significativas en función de dicha conflictividad en 
Francisco José Trillo-Padilla, Flor Zaldívar-Basurto, Juan García-García.

inadaptación familiar y escolar. Se discute evaluar las necesidades del menor considerando sus preferencias respecto al régimen de visitas para decidir jurídica y psicológicamente.

Palabras clave

Violencia de género; menor; víctimas; punto de encuentro familiar; conflictividad familiar.

The scientific literature offers few studies with a Spanish sample of the influence of conflictive divorce in the minor. However, studies such as Cantón, Cortés and Justicia (2002) and Cortés, Cantón and Cantón-Duarte (2011) show that the sons and daughters of separated or divorced parents have more behavioral and personal problems, as well as greater family conflicts and worse self-perception of their ability to deal with conflicts than those who live with both parents, paying special attention to those who live this process in a contentious way. Also, these manifestations usually occur and aggravate at the moment of encounter between the parents when making the change of visit from the custodial parent to the non-custodian. From the observation of this problem came the need for a mediating resource, the Family Meeting Point (FMP) that is used when this encounter between both parents is a threat to the emotional wellbeing of the child.

Most families immersed in processes of separation or contentious divorce, in short, processes that involve important vital crises, manifest a high degree of discrepancies, accusations and mutual recriminations that sometimes occur in the presence of the minor, which produces moments of Family emotional stress and even conflict. Obviously, when the family conflict becomes maltreatment, the problem is exacerbated, and there are less and less doubts that the lesser witnesses of gender violence also suffer the consequences of such abuse (Expósito, 2013). Other recent studies discuss the importance of the couple's relationship between the parents both for their family development and to promote the emotional stability of the child (Gómez, Martin, \& Ortega, 2017).
At a long-term international level, studies have been showing the adverse effects of gender-based violence on the psychological development of minors, such as the appearance of internalized and externalized disorders, difficulties in social relations, aggressive behavior, problems of adaptation and school performance, etc. (Lehman \& Rabenstein, 2002; Magen, Conroy \& Del Tufo, 2000; Osofsky, 1995). More recent studies show how witnessing violence towards the mother increases the chances of developing a trauma in childhood by $12.5 \%$ (Heinze, Cook, Wood, Dumadag \& Zimmerman, 2018, Van der Kolk, 2017), if the divorce is not appropriately solved it can affect all the members of the family including the children. Also, according to Papalia et al. (2010), young children are more anxious about divorce, have less realistic perceptions of what caused it and are more likely to be blamed.

In Spain, some studies (Corbalán \& Patró, 2003) carried out on testimonies of women victims of gender-based violence living in foster care, indicate that $66.6 \%$ of the children of the respondents were physically or psychologically ill. Likewise, in this study, the smallest witnesses to violence show many problematic behaviors in violence towards their peers (35\%), followed by violent behavior towards the mother (22\%), and, to a lesser extent, conflict in the school (10\%). Other reported symptoms were anxiety (32\%), sadness and isolation (27.5\%), fear of the abuser (27.5\%) and low school performance.

In the same sense, other studies indicate that the lowest witnesses of gender violence present more emotional and behavioral problems, symptoms of trauma, a higher probability of showing violent behaviors as well as suffering. This suggests this population (estimated at approximately 188,000 in Spain) to be considered as indirect victims of gender violence and the need to consider interventions tailored to their needs (Atenciano, 2009; Gavarrell, 2013). It is vitally important to pay attention to the emotional and behavioral problems of the children and to protect them with mechanisms of detection of psychological problems adapted to the peculiarities of each case (González- 
García et al., 2017). According to the 2015 macro-survey of the Government Delegation for Gender Violence (Delegación del Gobierno para la Violencia de Género, 2015), 63.6\% of women surveyed who suffer or have suffered genderbased violence state that their children witnessed or heard episodes of violence $(92.5 \%$ of these were under 18 years of age). $64.2 \%$ of those who had children who witnessed episodes of violence, said that in turn, they suffered violence.

Motivated by the data presented in these and other studies that show that acts of gender violence generate harmful consequences also in children, in our country, Law 8 (2015) on protection of children, reform of Act 1 (2004) on measures of integral protection against gender violence, which has led to the reconsideration of the child, a witness of gender violence, as a victim. Said reform has very important practical repercussions to be able to establish measures of protection to the child that allow judges and magistrates to suspend for the accused of gender violence the exercise of parental authority or custody of minors or order the suspension of visits of the accused (Law 8, 2015; Law 26, 2015). In addition, as Cala \& García (2014) fantastically show about the existing myths about violence, there are certain beliefs about the importance of the family and of the children from which it is considered that women should resign themselves and try to resolve their relationship of a couple for the good of the family and, above all, of the sons and daughters if they are minors.

However, although legislative reform is essential since it opens a door for child protection decisions that can be decisive in order to avoid and prevent very important problems, much remains to be done. Specifically, it would be necessary to have prior expert assessments that could advise Judges on the most timely decisions to be taken in each case depending on whether or not the child has witnessed or not family dispute independently to the existence of indictment for gender-based violence. It is well known that family dispute and/or mistreatment can occur without even a prior complaint and, of course, without judgment. In other words, protection of the child may also be necessary in cases where there is no indictment (nor complaint) of genderbased violence. Such assessments of the existence of family conflict, taking into account the views of the child, could improve decisions regarding when it would be appropriate to take measures to protect the child against the accused of gender violence. For example, when the best interest of the child would requires it, regime and parental authority should be suspended, even in cases where there is an indictment for gender-based violence. On the contrary, visitation regime should be facilitated with the accused supervised in the FMP when there are no indicators of victimization in the minor, nor risk.

The Family Meeting Point (FMP) is a community resource focused on those situations of family separation that, due to their conflict, require an objective and neutral intervention. this resource guarantees the safety and well-being of the child as well as that defends the prior interest of this one to maintain the fundamental right to relate to both parents after separation or divorce (Morte \& Lila, 2007). Regarding the procedure, the cases are referred to the FMP through the judge, who through a Protocol of Derivation and next to the judicial decision establishes measures and visits regime. In this process, in some cases, the child is not asked or evaluated psychologically to establish a visit regime according to their needs or preferences or to establish other types of interventions. As from the field of protection of minors, for years it has been advocated for the incorporation of a process of evaluation of the opinion of children and young people welcomed; their voice is the key to the development of quality interventions, and without this perspective, it tends to forget essential aspects to achieve the success of the intervention (Bravo \& Del Valle, 2009). Therefore, the need for the profile of the forensic psychologist, a figure that can respond to the demand of the judge with the data that it needs adjusting to the needs of the child (RodriguezDomínguez, Carbonell, \& Esparcia, 2014). All of these issues led to the pilot study of the FMP Service in Almería, which aims to analyze whether the cases derived from the Gender Violence Court (GVC) versus those coming from 
Francisco José Trillo-Padilla, Flor Zaldívar-Basurto, Juan García-García.

the Family Court (FC) differed in terms of family conflict, predisposition or agreement regarding the agreed visits regime, psychosocial adaptation of the minor, parental care, etc. The objective of this study is to evaluate the psychological and family adaptation of the child to cases referred by the specialized courts in Gender-Based Violence to the Service of Family Meeting Point (FMP) and on cases derived by the FC and to analyze if there are differences between both groups. The same objective is pursued by analyzing differences based on the reported existence of a family conflict. Finally, we want to study the evaluation of the perspective of the child concerning the visitation regime imposed, if he agrees with it and his opinion about it. Regarding the parents, this work aims to evaluate the caregiver capacity of the parents according to the court from which they come (GVC vs. FC) and the reported family conflict. The initial hypothesis is that family conflict would be transversal in both groups, regardless of the court of origin.

\section{Method}

\section{Participants}

The participants of the study were the beneficiary families of the FMP of Almería, a service from the Junta de Andalucía is a resource to protect women and children victims of gender violence. The sample has been divided into two groups. On the one hand, the families derived from the GVC and on the other hand, the derivatives from the FC. The sex distribution was 6 boys and 9 girls ranging between 8 and 14 years of age, with a mean of 9.7 years. Of the 15 cases studied, except in three, custody is the mother (all from the FC). Table 1 shows the mean, standard deviation and range for the sociodemographic data of the minors of both groups.
Table 1

Descriptive statistics of the sociodemographic data of the minors of both groups

\begin{tabular}{|c|c|c|c|c|c|c|}
\hline \multirow[t]{2}{*}{ Characteristic } & \multicolumn{3}{|c|}{$\begin{array}{c}\text { Gender Violence } \\
\text { Court (GVC) } \\
(\mathbf{n}=\mathbf{8}) \\
\end{array}$} & \multicolumn{3}{|c|}{$\begin{array}{l}\text { Family Court (FC) } \\
\qquad(\mathbf{n}=7)\end{array}$} \\
\hline & M & SD & Range & M & SD & Range \\
\hline Age & 9 & 1.41 & $8-12$ & 10.43 & 1.81 & $9-14$ \\
\hline \multirow[t]{2}{*}{$\begin{array}{l}\text { Time FMP } \\
\text { (Months) }\end{array}$} & 20.5 & 7.62 & $1-70$ & 20.57 & 8.94 & $1-70$ \\
\hline & $\mathrm{n}$ & $\%$ & & $\mathrm{n}$ & $\%$ & \\
\hline Gender & 8 & 100 & & 7 & 100 & \\
\hline Boy & 4 & 50 & & 2 & 71.4 & \\
\hline Girl & 4 & 50 & & 5 & 28.6 & \\
\hline \multicolumn{7}{|l|}{ Minor custody } \\
\hline Father & 0 & 0 & & 3 & 42.9 & \\
\hline Mother & 8 & 100 & & 4 & 57.1 & \\
\hline
\end{tabular}

The sample of the GVC group consisted of 16 parents with a mean age of 34.88 (S.D $=6.44$, range $=26$ to 45 years). The sample of parents that came from the FC had a mean age of 43.79 $(\mathrm{S} . \mathrm{D}=5.64$, range $=38$ to 55 years $)$. Table 2 shows the mean, standard deviation and range of the progenitors of both groups.

Table 2

Descriptive statistics of the sociodemographic data of the sample of parents of both groups

\begin{tabular}{|c|c|c|c|c|c|c|}
\hline \multirow[t]{2}{*}{ Characteristic } & \multicolumn{3}{|c|}{$\begin{array}{c}\text { Gender Violence Court } \\
\text { (GVC) } \\
(\mathrm{n}=16)\end{array}$} & \multicolumn{3}{|c|}{$\begin{array}{c}\begin{array}{c}\text { Family Court } \\
(\mathrm{FC}) \\
(\mathrm{n}=14)\end{array}\end{array}$} \\
\hline & M & SD & Range & M & SD & Range \\
\hline Age & 34.88 & 6.44 & $26-45$ & 43.79 & 5.64 & $38-55$ \\
\hline Number of children & 1.75 & 0.63 & $1-3$ & 1.79 & 0.97 & $1-4$ \\
\hline \multirow[t]{2}{*}{ Separate Time (Months) } & 62.5 & 33.39 & $12-110$ & 56.57 & 36.67 & $7-105$ \\
\hline & $\mathrm{n}$ & $\%$ & & $\mathrm{n}$ & $\%$ & \\
\hline \multicolumn{7}{|l|}{ Gender } \\
\hline Male & 8 & 50 & & 7 & 50 & \\
\hline Female & 8 & 50 & & 7 & 50 & \\
\hline \multicolumn{7}{|l|}{ Educational Level } \\
\hline Basic & 7 & 43.8 & & 5 & 40 & \\
\hline Middle & 8 & 50 & & 7 & 50 & \\
\hline Higher & 1 & 3.3 & & 2 & 10 & \\
\hline
\end{tabular}

The evaluation protocol composed by a semi-structured interview and the application of standardized instruments to explore each member of the family individually is described below.

Interview with parents. An interview was conducted with each of the parents separately to collect information on their sociodemographic data and the relationship with the child as well as to know the vision about the FMP and its visitation regime. 
Interview with the child. The interview explored the relationship with each of their parents. In the same way, he/she was asked if he/she had witnessed episodes of discussion between his/her parents and how they were lived with him/her to evaluare the possible family conflict experienced by the minor. The Family Dispute variable was categorized by asking about five blocks of questions: Frequency, with three questions about the assiduity of the discussions; Intensity, with five questions about the liveliness of the discussions; Resolution, where the minor were asked three questions about how their parents solved the conflict; Content of the discussions, with three questions and the Perceived threat of the child in these episodes with five other questions. With a total of 19 items, the Family Conflict variable in Low: 0-4, Moderate: 5-9, High: $10-15$ and Very High: +15 were categorized. From there, they were merged into two unique categories: High-Very High and LowModerate to perform a statistical analysis more focused on extreme values. Thus, the high-very high category was delineated as the one in which the minors had witnessed at least one episode of violence at home and the category of lowmoderate conflict as the one in which the minors had not witnessed family violence, but they were aware of the tension or conflict between their parents.

TAMAI. (Test Autoevaluativo de Adaptación Infantil). Self-Assessment Multifactorial Test for Children's Adaptation (Hernández, 2002). It evaluates the degree of personal, social, school and family adaptation of the child from seven scales: general maladaptation, personal maladjustment, school maladjustment, social maladjustment, family maladjustment, mother adequacy and parent adjustment. Two subgroups were differentiated by age: 13 minors in the range of $8-12$ years and two minors in the range of 12-14 years. It includes two auxiliary scales of reliability, such as pro-image and contradictions. This instrument has adequate psychometric properties according to the author (Reliability $\alpha=0.87$, Cronbach's alpha $=0.92$ ). In all dimensions, higher scores imply higher levels of maladaptation. The scoring of sub-factors is performed using a scale with scores ranging from 1 to 7 that corresponds to the following levels and percentiles (Lastra, Martínez-Chamorro, \& Luzuriaga, 2001). 1: Very Low (Pc 1-5); 2: Low (Pc 6-20); 3: Almost Low (Pc 21-40); 4: Medium (Pc 41-60); 5: Almost High (Pt 61-80); 6: Alto (Pc 81-95); 7: Very High (Pc 96-99).

CUIDA. (Cuestionario para la Evaluación de Adoptantes, Cuidadores, Tutores y Mediadores). Questionnaire for the Evaluation of Adopters, Caregivers, Tutors and Mediators (Bermejo et al., 2006). It assesses the ability of a subject to provide adequate care and care to a dependent person (biological child, adopted or in custody). The questionnaire contains the following primary scales: altruism, openness, assertiveness, selfesteem, ability to solve problems, empathy, emotional balance, independence, flexibility, reflexivity, sociability, frustration tolerance, ability to establish attachment or attachment, of grief and the following second-order factors: Responsible care, sensitivity to others, affective care and aggressiveness. The result of the test is performed through an algorithm where the profile of the subject is shown with a graph with the very low-low 1-3; Moderate 4-6 and high-very high 7-9. According to García, Estévez $\&$ Letamendía (2007), with an estimate of the coefficient of reliability $\alpha=0.77$.

\section{Procedure}

Minor users of FMP of Almería were selected who met the required age, between 8 and 14 years and who accepted the participation. Twenty-seven families who were eligible for the study were selected. 12 of whom declined to cooperate with the study when informed. First, the individual parents contacted each parent inviting them to participate in the study and make an appointment. Once mentioned, each family that participated in the study was informed of an informed consent that both parents must sign where they agreed to conduct an individual interview and complete the questionnaires and at the same time allowed the child to do the same. The interviews were conducted individually at 
Francisco José Trillo-Padilla, Flor Zaldívar-Basurto, Juan García-García.

the FMP facility and had one hour for the parents and about 45 minutes for the child. The study was divided into two groups, on the one hand, group 1 composed of 8 minors and their progenitors derived by the GVC and group 2, which was composed of 7 minors and their families whose origin was the $\mathrm{FC}$ due to submerging in a divorce process. The same evaluator interviewed all participants.

\section{Analysis of data}

In order to estimate the possible dependence between the GVC vs. FC group as a function of the reported family conflict, a Chi-Squared test was performed for independent samples, estimating the coefficient $r$ (phi) as the effect size. Since the samples are small, the p-value was estimated by exact inference.

On the other hand, we analyzed the possible statistically significant differences in the scores obtained between the TAMAI and the CUIDA subscales according to the court of provenance and according to the reported family dispute, a Mann-Whitney $U$ test was performed for samples independent, estimating the size of the effect $r$ (Rosenthal, 1991) for each analysis. As in the previous analysis, since the samples are small, the p-value was estimated by exact inference.

All analyses were performed with the SPSS program, version 21 (IBM Corp. Released, 2012).

\section{Results}

The degree of the family dispute of each child was analyzed, establishing two degrees of family dispute (see section variables and instruments). Based on their responses to the interview on this aspect, it was observed that independently of the group (GVC vs. FC) to which $60 \%$ of the children studied belonged; they had witnessed some episode of violence between their parents. Although, the high level of conflict is more significant in the GVC group (75\%) than in the FC group $(42.9 \%)$, this difference is not statistically significant (Chi Square $=1.6 ; p$ (exact) $=0.31 ; r=0.32$ ), perhaps due to the sample size, although the estimated effect can be considered medium.

Regarding the results derived from TAMAI, in our sample there were no statistically significant differences between the subscales of this test and the group to which the children belonged (GVC vs. FC). However, when analyzed in terms of family conflict, there were statistically significant differences in two of the TAMAI subscales (family and school maladjustment). The medians of family maladjustment in the groups of low family conflict are 2.5, compared to the high that is $3.5(U=48.50 ; Z=2.61 ; p$ (exact) $=$ $0.08, r=0.67)$. Regarding comparisons of family conflictive, it was found that children from the high-very high family conflict group show higher scores in school maladjustment $(U=45.50, Z=$ 2.26, $p$ (exact) $=0.02, r=0.58$ ). Respecting the results obtained in the CUIDA with the parents, only statistically significant differences are found between the groups of GVC vs. FC in the subscale capacity to establish attachment $(U=160.50 ; Z$ $=2.04 ; p($ exact $)=0.04 ; r=0.37)$.

Regarding the perspective of the child on their own visitation regime (table 3), 75\% of the children in the GVC group would change it; and of these, $50 \%$ to be less time to his father. In the same way, in the three cases that would change the visits regime $(42.9 \%)$ of the children in the FC group would do so to spend less time with their non-custodial parent, one of them the mother.

Table 3

Opinion of the minor about his Visitation Regime

\begin{tabular}{|c|c|c|c|c|c|c|c|c|}
\hline \multirow{4}{*}{$\begin{array}{c}\text { Type } \\
\text { Gender } \\
\text { Violence } \\
\text { Court } \\
\text { n=8 }\end{array}$} & \multicolumn{3}{|c|}{ Want to see NCP* } & \multirow{2}{*}{\multicolumn{2}{|c|}{$\begin{array}{r}\text { Vision of } \mathbf{V R} \mathbf{R}^{* *} \\
\text { Cases }\end{array}$}} & \multicolumn{3}{|c|}{ Would change VR } \\
\hline & & Cases & $\%$ & & & & Cases & $\%$ \\
\hline & Yes & 6 & $75 \%$ & Good & 4 & Yes & 6 & $75 \%$ \\
\hline & No & 2 & $25 \%$ & $\begin{array}{l}\text { Bad } \\
\text { Regular }\end{array}$ & $\begin{array}{l}3 \\
1\end{array}$ & No & 2 & $25 \%$ \\
\hline Family & Yes & 3 & $42.9 \%$ & Good & 4 & Yes & 4 & $57.1 \%$ \\
\hline $\begin{array}{c}\text { Court } \\
n=7\end{array}$ & No & 4 & $57.1 \%$ & $\begin{array}{l}\text { Bad } \\
\text { Regular }\end{array}$ & $\begin{array}{l}3 \\
0\end{array}$ & No & 3 & $42.9 \%$ \\
\hline
\end{tabular}

\section{Discussion}

Family dispute appears in $60 \%$ of the families evaluated, although this is greater in the group 
that comes from the GVC (75\% of our sample). However, in relation to the court of origin, there are no significant differences in the child's adjustment (measured through TAMAI) or in the caregiving capacity of their families (measured from CUIDA). In this sense, it seems that the most predictive independent variable is not the court of provenance but the level of conflict reported by the minors. This can be explained by the fact that many cases of gender violence are not reported and, on many occasions, violence against women and family conflict tends to be solved more by divorce than by denunciation. Thus, conflict and violence of gender or family also occurs in cases not reported, children who have witnessed the conflict of their parents feel less satisfied with their family and have greater problems of school adaptation, as can be seen from the differences found in the TAMAI subscales. On this idea, there are already studies that provide data on the effect of the child's exposure to family violence, both at academic and interpersonal level (Clark \& Graham-Bermann, 2017).

When analyzing the child's perspective on his visitation regime with the non-custodial parent, $75 \%$ of the GVC children and $42 \%$ of the FC group would change it. It is important to emphasize that $50 \%$ of the children who would like to change their visitation regime would do so to spend less time with their father, which seems to indicate how it affects the perspective of the child regarding the reported conflict to their decision making on their desire to spend more or less time with his father. It should be emphasized that another result of this study is that parents categorized as highly conflictive have more problems in establishing attachment bonds with their children, as can be seen from the results obtained with the CUIDA instrument.

The fact that exposure to violence or domestic conflict clearly increases the risk of presenting significant psychological problems, even in minors (in addition to the consequences it causes in women) justifies the design of specific evaluative tools that allow early detection of these situations. These evaluative tools' objective is to prevent and/or alleviate such problems, as well as to assist the counseling of Judges and Magistrates, regardless of whether there is an accusation for gender abuse since conflict and domestic violence is also frequently present in cases that come from the Family Court. Such evaluation protocols could help advise the judge in which cases the existence of family conflict advise to determine measures to protect the child against the parent accused of gender violence. Also when, despite such an accusation, the nonexistence of family conflict witnessed by the minor and his desire to continue to interact with his non-custodial parent would advise a supervised visitation regime, guaranteeing the right to interact with both parents. In the same vein, such evaluations would also be essential to make more informed decisions regarding the supervision of the visitation regime in those families with indicators of a high family dispute, although this has not been officially denounced.

It is necessary to emphasize the importance of taking into account the perspective of the child in the experience of family mistreatment, few studies on this subject that include the information of the minor in its evaluative protocols and, however, this information, well extracted and interpreted, can be maximally relevant (Asensi \& Díaz, 2016; Muñoz \& del Campo Cámara, 2015). In this sense, this study has evaluated the perspective of the child on a family dispute and their opinion regarding the visitation regime, an important and sometimes little observed aspect in the contentious. This component is undoubtedly significant in the adaptation of the children with their own parents and family and serves as a predictor of possible psychological consequences.

It is obvious to indicate the limitations of the results of this work, its exploratory nature, the limited fieldwork time (9 months) and the small size of the sample, due to the latter, partly due to the low willingness of users to collaborate in the project. Study as informing them that this research neither favors nor harm their conditions in the FMP chose not to participate. Therefore, it is necessary to indicate for the generalization of these results to replicate this work with a larger sample. 
Francisco José Trillo-Padilla, Flor Zaldívar-Basurto, Juan García-García.

\section{Acknowledgements}

To the parents and minors of the PEF of Almeria, as well as the whole professional team for their participation and implication on this study, without them this article were not possible.

This research was partially developed on the frame of the financed Project $\mathrm{I}+\mathrm{D}+\mathrm{i}$ "Análisis Jurídico y Cuantitativo de la Violencia en la Infancia y Adolescencia: Propuestas de Intervención Socio-Legal subvencionado por MINECO (DER2014-58084-R)" and for the Project "Emple@ Joven I+D+i" (2015) of the Consejería de Economía, Innovación, Ciencia y Empleo of the Junta de Andalucía in cooperation with COVID S.C.A.

\section{References}

Asensi, L. F., \& Díaz, M. (2016). Evaluaciones Psicológico-Forenses en asuntos de Violencia de Género. Errores habituales y propuestas de mejora. Información psicológica, 111, 103-119. http://dx.medra.o $\mathrm{rg} / 10.14635 /$ IPSIC.2016.111.8

Atenciano, B. (2009). Menores expuestos a violencia contra la pareja: notas para una práctica clínica basada en la evidencia. Clínica y Salud, 20(3), 261-272. Retrieved from http://scielo.isciii.es/scielo.php?script $=$ sci_abstract\&pid $=$ S1130-52742009000 300007

Bermejo, F. A., Estévez, I., García, M. I., GarcíaRubio, E., Lapastora, M., Letamendía, P., ... Velázquez de Castro,

F. (2006). CUIDA. Cuestionario para la evaluación de adoptantes, cuidadores, tutores y mediadores. Madrid: TEA Ediciones.

Bravo, A., \& Del Valle, J. F. (2009). Crisis y revisión del acogimiento residencial. Su papel en la protección infantil. Papeles del psicólogo, 30(1), 42-52. Retrieved from http: //www.papelesdelpsicologo.es/pdf/1655.pdf

Cala, M. J., \& García, M. (2014). Las experiencias de mujeres que sufren violencia en la pareja y su tra\#nsito por el sistema judicial: ¿Qué esperan y qué encuentran? Anales de la Cátedra Francisco Suárez, 48, 81-105. Retrieved from http://revistaseug.ugr.es/index.php/ac fs/article/view/2781

Cantón, J., Cortés, M. R., \& Justicia, M. D. (2002). Las consecuencias del divorcio en los hijos. Psicopatología Clínica, Legal y Forense, 2(3), 47-66. Retrieved from https://masterforense.com/pdf/2002/2 002art16.pdf

Clark, H., \& Graham-Bermann, S. A. (2017). The impact of intimate partner violence on children. In P. Dolan, \& N. Frost (Eds.), The Routledge handbook of global child welfare (199- 210). Taylor \& Francis.

Corbalán, J., \& Patró, R. (2003). Consecuencias psicológicas de la violencia familiar: mujeres maltratadas e hijos de hogares violentos. En Conferencia impartida en II Jornadas sobre Mujer y Salud: Interacción de los contextos familiar y laboral. Murcia, Epaña.

Cortés, M. R., Cantón, J., \& CantónDuarte, D. (2011). Estructura del hogar y conflictividad entre los padres. International Journal of Developmental and Educational Psychology, 1(2), 503-510. Retrieved from http://www.redalyc.org/pdf/3498/349 832329050.pdf

García, M. I., Estévez, I., \& Letamendía, P. (2007). El CUIDA como instrumento para la valoración de la personalidad en la evaluación de adoptantes, cuidadores, tutores y mediadores. Psychosocial Intervention, 16(3), 393-407. Retrieved from http://scielo.isciii.es/scielo.php?script $=$ sci abstract\&pid $=$ S1132-05592007000 300007

Delegación del Gobierno para la Violencia de Género. (2015). Macroencuesta de Violencia contra la Mujer. Madrid: Ministerio de Sanidad, Servicios Sociales e Igualdad.

Expósito, F. (2013). Problemáticas de los menores expuestos a violencia de género. In A. M., Rosser Limiñana, E., Villegas Castrillo, \& R. Suría Martínez, (Coords), Intervención con menores expuestos a violencia de género. 
Guía para profesionales (pp. 35-52). España: Limencop.

Gavarrell, C. (2013). Consecuencias psicológicas del maltrato en menores expuestos a violencia de género. Regulación Emocional, Funciones Ejecutivas y Autoconcepto (Doctoral dissertation). Universidad de Valencia, España.

Gómez, O., Martín, L., \& Ortega, R. (2017). Conflictividad parental, divorcio y ansiedad infantil. Pensamiento psicológico, 15(2), 67-78. https://doi.org/10.11144/Javerianac ali.PPSI15-2.cpda

González, C., Bravo, A., Arruabarrena, I., Martín, E., Santos, I., \& Del Valle, J. F. (2017). Emotional and behavioral problems of children in residential care: Screening detection and referrals to mental health services. Children and Youth Services Review, 73, 100-106. https://doi.org/10.1016/j.child youth.2016.12.011

Heinze, J. E., Cook, S. H., Wood, E. P., Dumadag, A. C., \& Zimmerman, M. A. (2018). Friendship attachment style moderates the effect of adolescent exposure to violence on emerging adult depression and anxiety trajectories. Journal of youth and adolescence, 47(1), 177-193. https://doi.org/10.1007/s10 964-017-0729-x

Herna\#ndez, P. (2002). Test Autoevaluativo Multifactorial de Adaptacio\#n Infantil (TAMAI). Madrid: TEA.

IBM Corp. Released. (2012). IBM SPSS Statistics for Windows, Version 21.0. Armonk, NY: IBM Corp.

Lastra, I., Martínez, M. J., \& Luzuriaga, C. (2001). El test autoevaluativo multifactorial de adaptación infantil (TAMAI). ¿Útil en el cribado de psicopatología infanto-juvenil? Informaciones Psiquiátricas, 166, 191-203.

Law 8. (2015, July 22). Modificación del sistema de protección a la infancia y a la adolescencia. Boletín Oficial del Estado (BOE), 175, 61871.

Law 26. (2015, July 28). Modificación del sistema de protección a la infancia y a la adolescencia. Boletín Oficial del Estado (BOE), 180.

Act 1. (2004, December 28). Medidas de Protección Integral contra la Violencia de Género. Boletín Oficial del Estado (BOE), 313.

Lehmann, P., \& Rabenstein, S. (2002). Children exposed to domestic violence: the role of impact, assessment, and treatment. In A. R. Roberts, Handbook of Domestic Violence Intervention Strategies. Policies, Programs, and Legal Remedies (343-364). New York, NY: Oxford University Press.

Magen, R. H., Conroy, K., \& Del Tufo, A. (2000). Domestic violence in child welfare preventative services: Results from an intake screening questionnaire. Children and Youth Services Review, 22(3), 251-274. https://doi.org/10.1016/S0190-74 09(00)00080-3

Morte, E., \& Lila, M. (2007). La alternativa al conflicto: Punto de Encuentro Familiar. Intervención Psicosocial, 16(3), 289-302. Retrieved from http://scielo.isciii.es/scielo.php?script $=$ sci_arttext\&pid $=$ S1132-055920070003 00001

Muñoz, J. M., \& del Campo, M. (2015). La evaluación pericial psicológica de idoneidad de custodia y régimen de visitas en los procedimientos de violencia de género en el contexto legal español. Psicopatología Clínica Legal y Forense, 15(1), 131-154. Retrieved from https://masterfore nse.com/pdf/2015/2015art8.pdf

Osofsky, J. D. (1995). The effect of exposure to violence on young children. American Psychologist, 50(9), 782-788. https://doi.org /10.1037/0003-066X.50.9.782

Papalia, D., Wendkos, S., \& Duskin, R. (2010). Psicologi\# a del Desarrollo. Mexico: McGraw Hill.

Rodríguez-Domínguez, C., Carbonell, X., \& Esparcia, A. J. (2014). Revisión conceptual del peritaje psicológico en relación a la Custodia de Menores en Cataluña. Anuario de Psicología Jurídica, 24 (1), 19-29. https://d oi.org/10.1016/j.apj.2014.07.001 
Francisco José Trillo-Padilla, Flor Zaldívar-Basurto, Juan García-García.

Rosenthal, R. (1991). Meta-analytic procedures for social research. Newbury Park; CA: SAGE. doi:/10.4135/9781412984997

Van der Kolk, B. A. (2017). Developmental Trauma Disorder: Toward a rational diagnosis for children with complex trauma histories. Psychiatric annals, 35(5), 401-408. https://doi.org/10.3928/00485713 $-20050501-06$

\section{Notes}

* Research article. 